\title{
Analisis Pola dan Intensitas Curah Hujan Berdasarkan Data TRMM di Sulawesi Tenggara
}

\author{
Erna Yulisari ${ }^{1)}$, Muliddin ${ }^{2)}$, Jamal Harimuddin \\ ${ }^{1}$ Jurusan Geografi FITK Universitas Halu Oleo \\ ${ }^{2}$ Jurusan Geografi FITK Universitas Halu Oleo \\ ${ }^{3}$ Jurusan Geografi FITK Universitas Halu Oleo
}

\section{Email:ernayulisari2597@gmail.com}

\begin{abstract}
Abstrak: Cuaca dan iklim merupakan sebuah proses fenomena di atmosfer yang keberadaannya sangat penting dalam berbagai aktivitas kehidupan. Perhatian mengenai informasi cuaca dan iklim semakin meningkat seiring dengan meningkatnya fenomena alam yang tidak lazim terjadi atau biasa disebut dengan cuaca ekstrim yang sulit untuk dikendalikan dan dimodifikasi. Penelitian ini bertujuan untuk mengetahui pola dan intensitas curah hujan berdasarkan data TRMM di Sulawesi Tenggara berdasarkan aspek temporal. Metode analisis data yaitu analisis korelasi dan uji signifikan untuk mengetahui hubungan data TRMM dengan data stasiun curah hujan, serta menggunakan persamaan Mononobe untuk intensitas curah hujan. Hasil penelitian ini didapatkan bahwa pola hujan di Sulawesi Tenggara merupakan pola region $A$ tipe monsunal dengan ciri terjadi puncak musim hujan yang terjadi antara bulan Desember, Januari, Februari dan puncak musim kemarau terjadi antara Bulan Agustus dan September. Kecendrungan intensitas curah hujan mengalami kenaikan dengan kala ulang yang lebih lama.
\end{abstract}

\section{Kata Kunci: Curah Hujan, TRMM, Monsunal}

Abstract: Weather and climate are a process of phenomena in the atmosphere whose existence is very important in various activities life. Concern about weather and climate information is increasing along with the increase in natural phenomena that are not uncommon or commonly referred to as extreme weather that are difficult to control and modify. This study aims to determine rainfall patterns and intensity based on TRMM data in Southeast Sulawesi based on temporal aspects. Data analysis method is correlation analysis and significant test to determine the relationship of TRMM data with rainfall station data, and using the Mononobe equation for rainfall intensity. The results of this study found that the pattern of rain in Southeast Sulawesi is a type of Region A Monsunal pattern characterized by the peak of the rainy season which occurs between December, January, February and the peak of the dry season occurs between August and September. The intensity of rainfall increases with a longer return period.

Keywords: Precipitation, TRMM, Monsoonal 


\section{PENDAHULUAN}

Sulawesi Tenggara memiliki dua musim, yaitu musim kemarau dan penghujan. Musim kemarau terjadi antara bulan Juni dan September, dimana angin Timur yang bertiup dari Australia tidak banyak mengandung uap air, sehingga mengakibatkan musim kemarau. Sebaliknya musim hujan terjadi antara bulan Desember dan Maret, dimana angin Barat yang bertiup dari Benua Asia dan Samudera Pasifik banyak mengandung uap air sehingga terjadi musim hujan. Keadaan seperti itu berganti setiap setengah tahun setelah melewati masa peralihan pada bulan April-Mei dan Oktober-November. Tinggi rendahnya suhu udara dipengaruhi oleh letak geografis wilayah dan ketinggian dari permukaan laut. Sulawesi Tenggara yang terletak di daerah khatulistiwa dengan ketinggian pada umumnya di bawah 1.000 meter, sehingga beriklim tropis.

Cuaca dan iklim merupakan sebuah proses fenomena di atmosfer yang keberadaannya sangat penting dalam berbagai aktivitas kehidupan. Perhatian mengenai informasi cuaca dan iklim semakin meningkat seiring dengan meningkatnya fenomena alam yang tidak lazim terjadi atau biasa disebut dengan cuaca ekstrim yang sulit untuk dikendalikan dan dimodifikasi, cuaca berkaitan dengan aktivitas manusia seharihari, baik secara langsung maupun tidak langsung. Salah satu unsur cuaca dan iklim adalah curah hujan. Curah hujan diukur dengan menggunakan penakar hujan. Terdapat kurang lebih sebanyak 54 pos hujan yang tersebar di wilayah Sulawesi Tenggara namun hanya 4 pos hujan yang memiliki data yang lengkap selama sepuluh tahun sisanya hanya memiliki kelengkapan data selama dua hingga lima tahun saja.

Intensitas curah hujan di wilayah tropik pada umumnya tinggi. Sementara itu di Indonesia, presentase curah hujan yang diterima bervariasi antara $8 \%$ sampai
$37 \%$ dengan rata-rata $22 \%$. Sebagai perbandingan nilai tertinggi di Bavaria, Jerman adalah 3.7\%. Di Bogor, lebih dari $80 \%$ curah hujan yang diterima terjadi dengan curah paling sedikit $20 \mathrm{~mm}$ (Mulyono, 2014)

Perkembangan teknologi terkini berupa teknologi remote sensing (satelit) mampu membuat terobosan dalam hal informasi curah hujan karena dengan teknologi remote sensing mampu melakukan pengukuran presipitasi dari jarak jauh (remote). Daerah-daerah yang sebelumnya sangat sulit atau hampir mustahil dilakukan pengukuran curah hujan dengan teknologi ini memungkinkan didapatkan data curah hujan, sehingga secara sederhana dapat dikatakan bahwa dengan teknologi satelit dapat didapatkan data curah hujan kapan saja dan di mana saja. Khusus untuk wilayah tropis, saat ini telah tersedia sebuah perangkat remote sensing yang melakukan misi pengukuran curah hujan di wilayah tropis menggunakan satelit TRMM (Tropical Rainfall Measurement Mission).

Satelit TRMM membawa 5 sensor utama yaitu PR (Precipitation Radar), TMI (TRMM Microwave Imager), VIRS (Visible Infrared Scanner), LIS (Lightning Imaging Sensor) dan CERES (Clouds and Earth's Radiant EnergySystem), merupakan wahana yang sangat tepat digunakan untuk studi karakteristik dan mekanisme curahhujan tropis. (Zubaidah, 2012).

\section{METODE PENELITIAN}

lokasi penelitian berada di Sulawesi Tenggara, yang secara astronomis terletak pada bagian selatan garis khatulistiwa, membentang dari Utara ke Selatan pada posisi $02^{\circ} 45^{\prime}-06^{\circ} 16^{\prime}$ Lintang dan $120^{\circ} 45^{\prime}$ - $124^{\circ} 45^{\prime}$ Bujur Timur. Berdasarkan posisi geografisnya, Provinsi Sulawesi Tenggara berada di: Sebelah Utara berbatasan dengan Provinsi Sulawesi Selatan dan Provinsi Sulawesi Tengah, Sebelah Selatan berbatasan dengan Laut Flores, Sebelah 
Timur berbatasan dengan Laut Banda, dan Sebelah Barat berbatasan dengan Teluk Bone (Gambar 1).

Letak Stasiun Hujan di Sulawesi Tenggara terlihat pada tabel berikut:

Tabel 1. Koordinat Pos Stasiun Curah Hujan Utama Di Sulawesi Tenggara

\begin{tabular}{clcc}
\hline No & \multicolumn{1}{c}{ Stasiun } & Lintang & Bujur \\
\hline 1 & $\begin{array}{l}\text { Stasiun Meteorologi } \\
\text { Maritim Kendari }\end{array}$ & -3.96 & 122.6 \\
& $\begin{array}{l}\text { Stasiun Klimatologi } \\
2\end{array}$ & -4.05 & 122.44 \\
& $\begin{array}{l}\text { Ranomeeto } \\
\text { Stasiun Meteorologi }\end{array}$ & -4.18 & 121.61 \\
& $\begin{array}{l}\text { Sangia Ni Bandera } \\
\text { Stasiun Meteorologi }\end{array}$ & -5.52 & 122.58 \\
& Betoambari & \\
\hline
\end{tabular}

Sumber: BMKG Ranomeeto

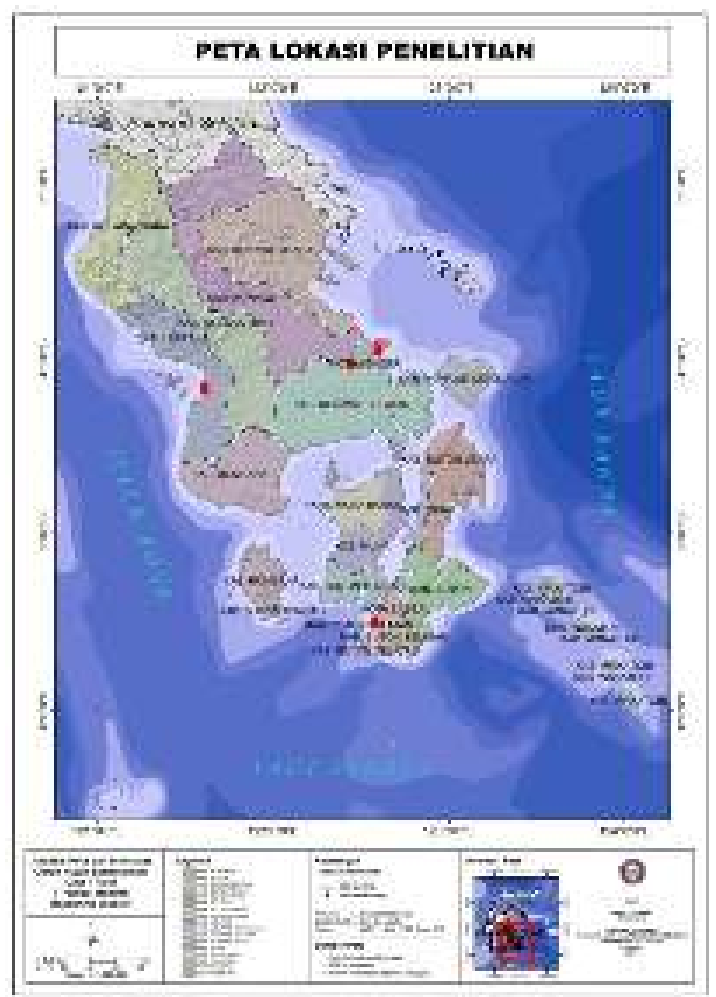

Gambar 1. Peta Lokasi Penelitian

\subsection{Tahap Pengolahan Data Penentuan Data Input}

Data utama yang digunakan adalah data hujan bulanan dari satelit TRMM jenis 3B43 periode data 2009 - 2018 berbentuk grid dengan resolusi spasial $0.25^{\circ} \times 0.25^{\circ}$. Data pendukung berupa data curah hujan bulanan permukaan periode tahun 2009-2019 dari 4 stasiun curah hujan utama di Sulawesi Tenggara.

\section{Pembuatan Peta Lokasi Penelitian}

Pembuatan peta lokasi penelitian bertujuan untuk membatasi wilayah kajian yang akan di teliti.

\section{Pengolahan data}

a. Akses dan pengolahan data nc (data TRMM) menggunakan software GrADS.

b. Pengolahan data curah hujan dari satelit TRMM dan 4 lokasi Stasiun Hujan, selanjutnya pengolahan data menggunakan Microsoft Office Excel, termasuk didalamnya dalam pembuatan grafik, tabel dan perhitungan nilai korelasi dan uji hipotesis.

c. Nilai $t_{\text {hitung }}$ kemudian dibandingkan dengan $t_{\text {tabel }}$. Nilai $t_{\text {tabel }}$ dikonfimasi sesuai dengan taraf $\alpha=0,5 \%$ dan $\mathrm{dk}$ $=\mathrm{N}-2$. Bila $\mathrm{t}_{\text {hitung }}>\mathrm{t}_{\text {tabel }} \rightarrow$ maka $\mathrm{H}_{0}$ tolak, dan berarti menerima Ha. Sedangkan bila $t_{\text {hitung }}<t_{\text {tabel}}$, maka tidak menolak $\mathrm{H}_{0}$, yang berarti menolak Ha. 


\section{Teknik Analisis Data}

Tahapan analisis data merupakan tahapan terakhir dalam proses penelitian ini. Analisis data dilakukan untuk menjawab permasalahan penelitian. Analisis yang digunakan dalam penelitian ini yaitu:

a. Ekstraksi Data Satelit TRMM

Data satelit TRMM format binary diekstraksi pada grid tertentu (wilayah domain penelitian) dengan mengunakan software Open Grads versi 2.0, Selanjutnya dilakukan konversi data binary menjadi data numerik. Data hasil konversi disusun sebagai series data bulanan tahun 2009 - 2018.

\section{b. Analisis Korelasi}

korelasi ini dilakukan untuk mengetahui seberapa besar tingkat kepercayaan yang didapatkan, kemudian dianalisa hubungan antara kedua data. Salah satu metode perhitungan koefisien korelasi yang digunakan dalam penelitian ini yaitu metode Pearson atau koefisien korelasi Pearson (Muttaqin, 2014)

Hal tersebut dirumuskan sebagai berikut :

$\mathbf{r}_{\mathrm{xy}}=\frac{n \sum X Y-\left(\sum X\right)\left(\sum \boldsymbol{Y}\right)}{\sqrt{\left\{n \sum X^{2}-\left(\sum X^{2}\right)\right\}\left\{n \sum Y^{2}-\left(\sum Y\right)^{2}\right\}}}$

Di mana:

$\mathrm{r}_{\mathrm{xy}}$ : koefisien korelasi $\mathrm{r}$ pearson

n: jumlah sampel/observasi

$\mathrm{x}$ : variabel bebas/variabel pertama

$\mathrm{y}$ : variabel terikat/variabel kedua.

Interpretasi terhadap harga atau koefisien korelasi secara konvensional diberikan oleh Guilford (1956) sebagai berikut:

Tabel 2. Interpretasi Koefisien Korelasi

\begin{tabular}{cc}
\hline Koefisien korelasi $\mathbf{r}$ & Interpretasi \\
\hline $0,80-1,00$ & Sangat tinggi \\
$0,60-0,80$ & Tinggi \\
$0,40-0,60$ & Cukup \\
$0,20-0,40$ & Rendah \\
$0,00-0,20$ & Sangat rendah \\
\hline
\end{tabular}

Sumber: Muttaqin, 2014

\section{c. Uji Hipotesis}

Hipotesis merupakan jawaban sementara terhadap pertanyaan penelitian. Oleh karena itu, perumusan hipotesis sangat berbeda dari perumusan pertanyaan penelitian. Rumusan-rumusan hipotesis penelitian, pada gilirannya sewaktu akan diuji dengan menggunakan metode statistika, perlu diterjemahkan dalam bentuk pernyataan simbolik. Simbolsimbol yang digunakan dalarn rumusan hipotesis statistika adalah simbol-simbol parameter. Parameter adalah besaranbesaran yang ada pada populasi (Azwar, 2005)

Dilakukan Pengujian hipotesis untuk mengetahui hubungan kedua data dengan asumsi sebagai berikut :

$\mathrm{H}_{\mathrm{o}}=>$ Tidak ada hubungan antara curah hujan TRMM dengan data Stasiun Hujan $\mathrm{H}_{\mathrm{a}} \Rightarrow$ Ada hubungan antara curah hujan TRMM dengan data Stasiun Hujan.

Menurut (Raharja, 2007) dalam menguji hipotesis tersebut Digunakan rumus sebagai berikut :

$$
t=r \cdot \frac{\sqrt{N-2}}{\sqrt{1-r^{2}}} \ldots \ldots \ldots \ldots
$$

dimana :

$\mathrm{t}=$ Probabilitas

$\mathrm{r}=$ Koefisien Korelasi

$\mathrm{N}=$ Jumlah periode

Untuk menarik kesimpulan dari hasil hipotesis maka perhitungan $\mathrm{T}_{\text {hitung }}$ dibandingkan dengan $\mathrm{T}_{\text {tabel }}$ dengan tingkat signifikan $0.05(5 \%)$. Kriteria penolakan dan penerimaan hipotesis Ho adalah sebagai berikut :Bila $T_{\text {hitung }}>T_{\text {tabel }} \rightarrow$ maka tolak $\mathrm{H}_{0}$, dan berarti menerima Ha. Sedangkan bila $\mathrm{t} \mathrm{T}_{\text {hitung }}<\mathrm{T}_{\text {tabel }}$, maka tidak menolak $\mathrm{H}_{0}$, yang berarti menolak $\mathrm{Ha}$

\section{d. Analisis Klimatologis Untuk Pola Hujan}

Analisis klimatologis dilakukan dengan menggunakan data hujan bulanan selama 10 tahun (2009-2018) untuk mengetahui pola hujan di wilayah studi. Pengolahan data hujan observasi dari stasiun hujan dan satelit TRMM, dihitung nilai rata-rata pada kedua data tersebut. Analisis data hujan observasi dari stasiun hujan di wilayah studi, digunakan nilai rata-rata aritmatika dari seluruh stasiun menggunakan persamaan rumus (Hariarta, 2013):

$$
\bar{X}=\frac{1}{n} \sum_{i=1}^{n} X i
$$

Dimana : 
$\overline{\mathrm{x}}=$ curah hujan rata-rata bulanan

$\mathrm{n}=$ jumlah data

$\mathrm{Xi}=$ curah hujan bulan ke- $\mathrm{i}$

e. Analisis Intesitas Curah Hujan

Besarnya intensitas curah hujan berbeda-beda tergantung dari lamanya curah hujan dan frekuensi kejadiannya. Intensitas curah hujan yang tinggi pada umumnya berlangsung dengan durasi pendek dan meliputi daerah yang tidak luas.

Metode yang biasa digunakan dalam perhitungan intensitas curah hujan adalah sebagai berikut (Suyono dan Takeda 1983 dalam Fauziah., dkk, 2013):

$$
\mathrm{I}=\frac{R_{24}}{24}\left(\frac{24}{t}\right)^{\frac{2}{3}}
$$

Dimana :

$\mathrm{I}=$ Intensitas curah hujan(mm/jam)

$\mathrm{t}=$ lamanya curah hujan/durasi curah hujan(jam)

R24=Curah hujan rencana dalam suatu periode ulang.

Hal pertama yang dilakukan adalah menjumlahkan data curah hujan bulanan, sehingga didapat jumlah total curah hujan per tahun kemudian dilakukan perhitungan intensitas hujan untuk beberapa durasi waktu, untuk menentukan nilai $\mathrm{R}_{24}$ terlebih di lakukan perhitungan untuk mencari nilai Sx (standar deviasi) kemudian dilakukan perhitungan untuk mendapatkan nilai analisis curah hujan maksimum 24 Jam $\left(\mathrm{R}_{24}\right)$ dengan menggunakan rumus Distribusi Gumbel:

Dimana:

$$
\mathbf{R}_{24}=\bar{X}+\frac{s_{X}}{s_{n}}\left(Y_{t}-Y_{n}\right) \ldots \ldots
$$

$\mathrm{R}_{24}=$ Besarnya curah hujan harian maksimum $24 \mathrm{jam}$ ( $\mathrm{mm} / 24 \mathrm{jam})$

$\mathrm{X}$ = Rata-rata curah hujan $(\mathrm{mm})$

Sx $=$ Deviasi Standard

$\mathrm{Yn}=$ Reduced mean

$\mathrm{Sn}=$ Reduced standard deviation

$\mathrm{Yt}=$ Reduced variasi sebagai periode ulang

\section{HASIL DAN PEMBAHASAN Analisis Korelasi}

Penelitian ini menggunakan uji satu arah (one-tail) dengan nilai pembanding Ttabel yang diperoleh dari :

$\mathrm{N}=12$ (jumlah sampel)

$\mathrm{Df}=\mathrm{N}-\mathrm{K}=12-2=10$

a. Hubungan curah hujan TRMM dengan Stasiun Meteorologi Maritim Kendari dengan $r=0,93986$

Uji statistik :

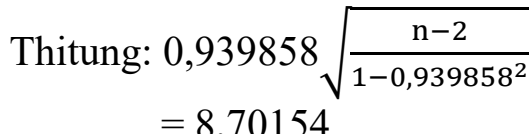

Tabel 3. Korelasi antara data curah hujanTRMM dengan curah hujan Stasiun Meteorologi Maritim Kendari

\begin{tabular}{c|c|c}
\hline BULAN & $\begin{array}{c}\text { TRMM } \\
\text { (mm/tahun) }\end{array}$ & $\begin{array}{c}\text { STASIUN } \\
\text { (mm/tahun) }\end{array}$ \\
\hline Januari & 226,523 & 198,766 \\
Februari & 310 & 196,721 \\
Maret & 275,263 & 231,483 \\
April & 239,966 & 168,378 \\
Mei & 361 & 233,903 \\
Juni & 370 & 234,788 \\
Juli & 261,897 & 220,262 \\
Agustus & 86,0146 & 80,3403 \\
September & 60 & 38,7056 \\
Oktober & 67 & $65,2 \mathrm{c} 5$ \\
November & 135 & 75,243 \\
Desember & 223 & 194,936 \\
r & \multicolumn{2}{c}{0,93986} \\
$\mathbf{T}_{\text {hitung }}$ & \multicolumn{2}{c}{2,70154} \\
$\mathbf{T}_{\text {tabel }}$ & \multicolumn{2}{c}{2,17881} \\
\hline
\end{tabular}

Sumber: Data penelitian tahun 2019

Berdasarkan hasil analisis korelasi yang dilakukan antara data curah hujan TRMM dengan curah hujan Stasiun Meteorologi Maritim Kendari didapatkan nilai korelasi sebesar 0,93986, nilai Thitung sebesar 8,70154 dan Ttabel sebesar 2,17881 dimana Thitung lebih besar dibandingkan dengan Ttabel

b. Hubungan curah hujan TRMM dengan Stasiun Klimatologi Ranomeeto dengan $r=0,94869$ Uji statistik :

Thitung: $0,94869 \sqrt{\frac{\mathrm{n}-2}{1-0,94869^{2}}}$
$=9,4875$

Tabel 4. Korelasi antara data curah hujan TRMM dengan curah hujan Stasiun Klimatologi Ranomeeto 


\begin{tabular}{c|c|c}
\hline BULAN & $\begin{array}{c}\text { TRMM } \\
\text { (mm/tahun) }\end{array}$ & $\begin{array}{c}\text { STASIUN } \\
\text { (mm/tahun) }\end{array}$ \\
\hline Januari & 178,928 & 147,836 \\
Februari & 270 & 238,488 \\
Maret & 268 & 295,361 \\
April & 222,962 & 208,699 \\
Mei & 297 & 321,405 \\
Juni & 300 & 277,907 \\
Juli & 223,883 & 265,289 \\
Agustus & 78,3634 & 97,76 \\
September & 63 & 79,51625 \\
Oktober & 74 & 124,25714 \\
November & 149 & 162,479 \\
Desember & $219 \quad 218,904$ \\
r & \multicolumn{2}{c}{0,94869} \\
Thitung $_{\text {T }}$ & \multicolumn{2}{c}{9,4875} \\
\hline tabel & \multicolumn{2}{c}{2,17881} \\
\hline
\end{tabular}

Sumber: Data penelitian tahun 2019

Berdasarkan hasil analisis korelasi yang dilakukan antara data curah hujan TRMM dengan curah hujan Stasiun Klimatologi Ranomeeto didapatkan nilai korelasi sebesar 0,94869 , nilai Thitung sebesar 9,48758, dan Ttabel sebesar 2,17881 dimana Thitung lebih besar dibandingkan dengan Ttabel.

c. Hubungan curah hujan TRMM dengan Stasiun Meteorologi Sangia Ni Bandera dengan $r=0,92561$

Uji statistik :

Thitung: $0,92561 \sqrt{\frac{\mathrm{n}-2}{1-0,92561^{2}}}$ $=7,73369$

Tabel 5. Korelasi antara data curah hujan TRMM dengan curah hujan Stasiun Meteorologi Sangia Ni Bandera

\begin{tabular}{c|c|c}
\hline BULAN & $\begin{array}{c}\text { TRMM } \\
\text { (mm/tahun) }\end{array}$ & $\begin{array}{c}\text { STASIUN } \\
\text { (mm/tahun) }\end{array}$ \\
\hline Januari & 135,999 & 145,761 \\
Februari & 207 & 192,872 \\
Maret & 262 & 254,5461 \\
April & 239,891 & 280,738 \\
Mei & 250 & 242,994 \\
Juni & 204 & 173,695 \\
Juli & 196,649 & 143,05 \\
Agustus & 66,4731 & 46,057 \\
September & 93 & 78,83 \\
Oktober & 103 & 137,612 \\
November & 140 & 134,793 \\
\hline
\end{tabular}

\begin{tabular}{ccc}
\hline Desember & 164 & \multicolumn{1}{c}{173,963} \\
$\mathbf{r}$ & & 0,92561 \\
$\mathbf{T}_{\text {hitung }}$ & & 7,73369 \\
$\mathbf{T}_{\text {tabel }}$ & \multicolumn{2}{c}{2,17881} \\
\hline
\end{tabular}

Sumber: Data penelitian tahun 2019

Berdasarkan hasil analisis korelasi yang dilakukan antara data curah hujan TRMM dengan curah hujan Stasiun Meteorologi Sangia Ni Bandera didapatkan nilai korelasi sebesar 0,92561, nilai Thitung sebesar 7,73369, dan Ttabel sebesar 2,17881 dimana Thitung lebih besar dibandingkan dengan Ttabel.

d. Hubungan curah hujan TRMM dengan Stasiun Meteorologi Betoambari dengan $r=0,98517$ Uji statistik :

$$
\text { Thitung: } 0,98517 \sqrt{\frac{\mathrm{n}-2}{1-0,985171^{2}}}
$$$$
=18,1569
$$

Tabel 6. Korelasi antara data curah hujan TRMM dengan curah hujan Stasiun Meteorologi Betoambari

\begin{tabular}{ccc}
\hline BULAN & $\begin{array}{c}\text { TRMM } \\
\text { (mm/tahun) }\end{array}$ & $\begin{array}{c}\text { STASIUN } \\
\text { (mm/tahun) }\end{array}$ \\
Januari & 187,886 & 199,492 \\
Februari & 212 & 203,239 \\
Maret & 190 & 206,023 \\
April & 179 & 207,173 \\
Mei & 199 & 195,528 \\
Juni & 215 & 230,954 \\
Juli & 108 & 106,814 \\
Agustus & 37,6021 & 32,18 \\
September & 32 & 55,88 \\
Oktober & 40 & 52,72 \\
November & 79 & 92,923 \\
Desember & 256 & 297,609 \\
r & \multicolumn{2}{c}{0,98517} \\
T $_{\text {hitung }}$ & \multicolumn{2}{c}{2,17869} \\
T $_{\text {tabel }}$ &
\end{tabular}

Sumber: Data penelitian tahun 2019

Berdasarkan hasil analisis korelasi yang dilakukan antara data curah hujan TRMM dengan curah hujan Stasiun Meteorologi Betoambari didapatkan nilai korelasi sebesar 0,98517 , nilai Thitung sebesar 18,1569, dan Ttabel sebesar 2,17881 dimana Thitung lebih besar dibandingkan dengan Ttabel. 


\section{Analisis Pola Curah Hujan}

Perhitungan analisis pola curah hujan dilakukan untuk melihat apakah kedua data yang digunakan memiliki grafik yang mirip atau berbeda, sehingga diperlukannya nilai rata-rata tiap bulan selama 10 tahun dari kedua data tersebut, dan untuk mengetahui nilai rata-rata data bulanan pada satelit TRMM dianalisis menggunakan aplikasi GraDs dengan script tertentu. Grafik hubungan curah hujan TRMM dan data stasiun memiliki korelasi yang kuat positif pada kedua unsur.

Berdasarkan grafik - grafik tersebut menunjukkan hubungan yang berbanding lurus, dimana pada saat curah hujan TRMM meningkat data dari StaMet juga mengalami peningkatan. Grafik hubungan tersebut terlihat seperti gambar berikut:

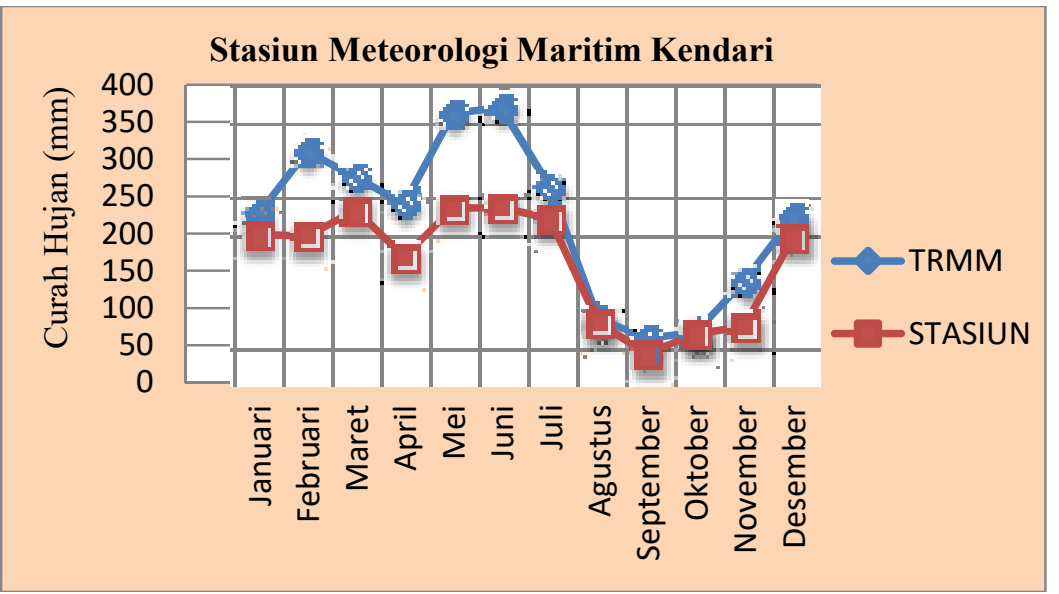

Gambar 2. Grafik hubungan curah hujan TRMM dan StaMar Kendari tahun 2009-2018

Grafik diatas terlihat persamaan pola namun untuk jumlah curah hujan yang terjadi ada perbedaan antara data dari TRMM dengan data dari Stasiun meteorologi Maritim Kendari dimana data dari TRMM pada bulan februari mengalami peningkatan berkisar antara 250-300 $\mathrm{mm}$ dan pada bulan maret mengalami penurunan berkisar 300-250 mm sedangkan untuk data dari stasiun pada bulan februari mengalami penurunan berkisar antara $250-200 \mathrm{~mm}$ dan bulan maret mengalami peningkatan berkisar antara 200-250 $\mathrm{mm}$, dan perbedaan selajutnya terjadi pada bulan juni data TRMM mengalami peningkatan berkisar antara 350-400 mm sedangkan data stasiun mengalami penurunan berkisar 250-200 $\mathrm{mm}$.

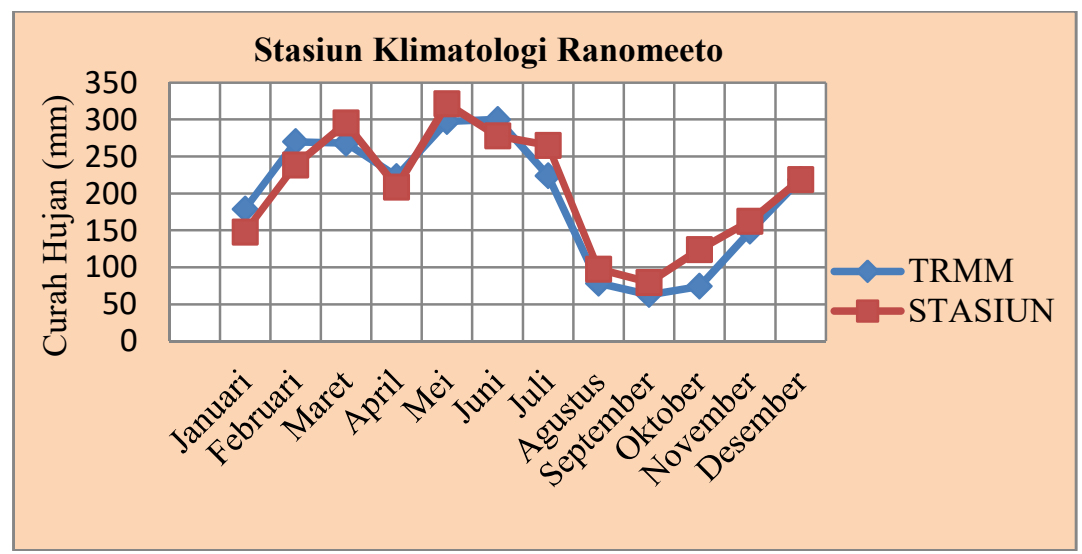

Gambar 3. Grafik hubungan curah hujan TRMM dan Stasiun Klimatologi Ranomeeto tahun 2009-2018 
Grafik diatas terlihat persamaan pola namun untuk jumlah curah hujan yang terjadi ada perbedaan antara data dari TRMM dengan data dari Stasiun meteorologi Ranomeeto dimana data dari TRMM pada bulan maret mengalami penurunan berkisar antara 300-250 mm sedangkan untuk data dari stasiun pada bulan maret mengalami peningkatan berkisar 250-300 $\mathrm{mm}$, dan perbedaan selajutnya terjadi pada bulan juni data TRMM mengalami peningkatan berkisar antara 300-350 $\mathrm{mm}$ sedangkan data stasiun mengalami penurunan berkisar antara 300$250 \mathrm{~mm}$.

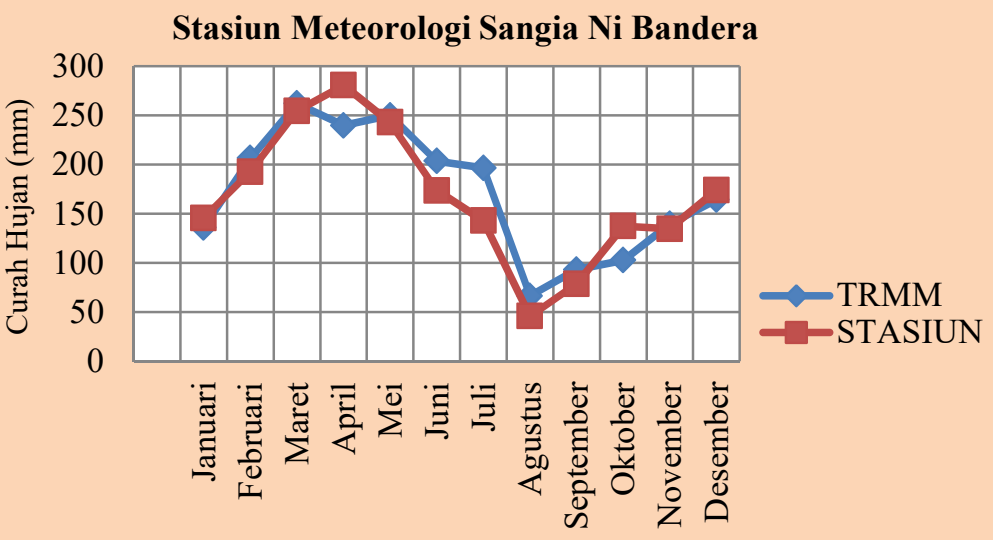

Gambar 4. Grafik hubungan curah hujan TRMM dan Stasiun Meteorologi Sangia Ni Bandera tahun 2009-2018

Grafik diatas terlihat persamaan pola namun untuk jumlah curah hujan yang terjadi ada perbedaan antara dari data TRMM dengan data dari Stasiun Meteorologi Sangia Ni Bandera, dimana data dari TRMM pada bulan april mengalami penurunan berkisar antara 250 $200 \mathrm{~mm}$ dan pada bulan mei mengalami peningkatan berkisar antara $200-250 \mathrm{~mm}$ sedangkan untuk data dari stasiun pada bulan april mengalami peningkatan berkisar antara 250-300 $\mathrm{mm}$ dan bulan mei mengalami penurunan berkisar 250-300 $\mathrm{mm}$, dan perbedaan selajutnya terjadi pada bulan november data TRMM mengalami peningkatan berkisar antara 100-150 mm sedangkan data stasiun mengalami penurunan berkisar antara 150-100 $\mathrm{mm}$.

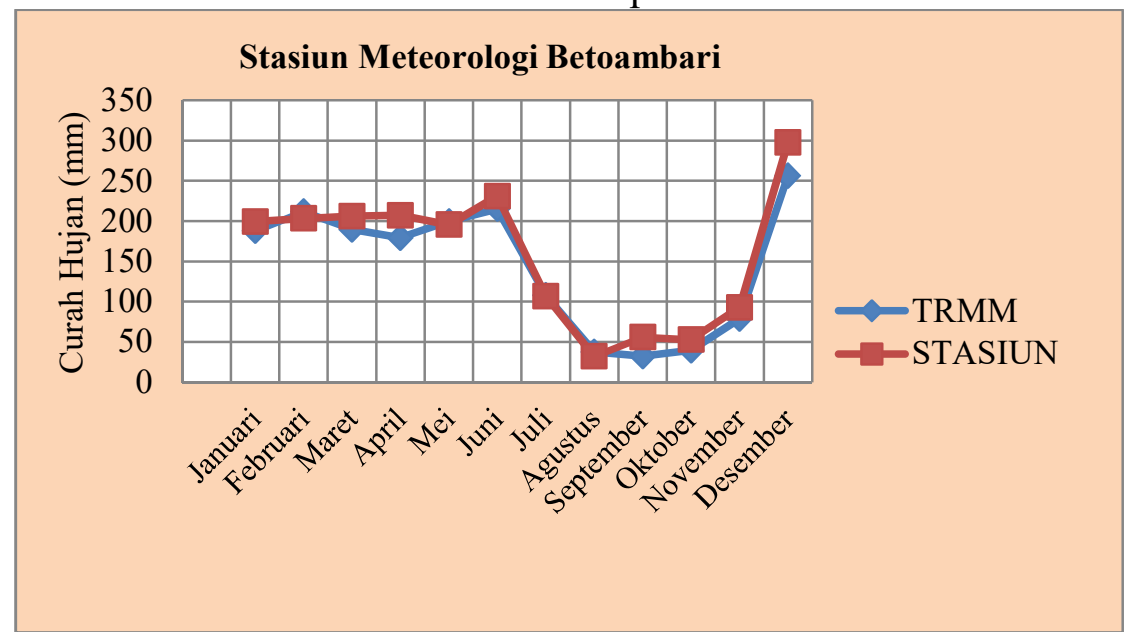

Gambar 5. Grafik hubungan curah hujanTRMM dan Stasiun Meteorologi Betoambari tahun 2009-2018

Grafik diatas terlihat persamaan pola namun untuk jumlah curah hujan yang terjadi ada perbedaan antara dari data
TRMM dengan data dari Stasiun Meteorologi BetoAmbari, dimana data dari TRMM pada bulan maret-april mengalami 
penurunan berkisar antara 200-150 mm dan pada bulan mei mengalami peningkatan berkisar 150-200 mm sedangkan untuk data dari stasiun pada bulan maret-april mengalami peningkatan berkisar antara $200-250 \mathrm{~mm}$ dan pada bulan mei mengalami penurunan berkisar antara 200-150 $\mathrm{mm}$, dan perbedaan selajutnya terjadi pada bulan septemberoktober data TRMM mengalami penurunan berkisar antara 50-0 mm pada bulan september dan bulan oktober mengalami peningkatan berkisar antara 0$50 \mathrm{~mm}$ sedangkan data stasiun mengalami peningkatan pada bulan september berkisar antara 50-100 $\mathrm{mm}$ dan bulan oktober mengalami penurunan berkisar antara 50-0 $\mathrm{mm}$.

\section{Analisis Intensitas Curah Hujan}

Dalam penelitian ini digunakan analisis persamaan Mononobe untuk menentukan intensitas curah hujan yang terjadi di wilayah Sulawesi Tenggara dengan durasi kurang lebih 24 jam.

Analisis intensitas curah hujan dapat diproses berdasarkan data curah hujan yang telah terjadi pada tahun-tahun sebelumnya. Perhitungan besarnya intensitas curah hujan dapat dipergunakan beberapa rumus empiris dalam hidrologi. Dalam penelitian ini dugunakan analisis Mononobe untuk menentukan intensitas curah hujan yang terjadi di wilayah Sulawesi Tenggara dengan durasi kurang lebih 24 jam. Analisis curah hujan memerlukan data curah hujan dalam kurun waktu tertentu. Dalam analisis semakin banyak seri data yang digunakan maka semakin kecil kesalahan dalam analisis.

Analisis untuk perhitungan intensitas curah hujan rencana dalam periode ulang $5,10,25$ dan 50 tahun dengan menggunakan persamaan Mononobe diperoleh data yang disajikan dalam Tabel 7

Tabel 7.Besaran intensitas curah hujan TRMM dengan durasi waktu 24 jam di Stasiun

Meteorologi Maritim Kendari

\begin{tabular}{c|c|c|c|c}
\hline \multirow{2}{*}{$\begin{array}{c}\text { Durasi } \\
\text { (Jam) }\end{array}$} & \multicolumn{4}{|c}{ Curah Hujan Harian Maksimum 24 Jam (R24) (mm/24 jam) } \\
\cline { 2 - 5 } & $\mathbf{5}$ Tahun & $\mathbf{1 0}$ Tahun & 25 Tahun & $\mathbf{5 0}$ Tahun \\
\cline { 2 - 5 } & $\mathbf{2 2 3 0 , 4 1}$ & $\mathbf{2 6 9 1 , 8 7}$ & $\mathbf{3 3 1 2 , 2 1}$ & $\mathbf{3 7 6 0 , 1 7}$ \\
\cline { 2 - 5 } & \multicolumn{4}{|c}{ Intensitas Hujan Rencana dengan rumus Mononobe (mm/Jam) } \\
\hline 0,08 & 9665,499 & 11665,24008 & 14353,48842 & 16294,72664 \\
0,16 & 4832,75 & 5832,620042 & 7176,744208 & 8147,363322 \\
0,25 & 3092,96 & 3732,876827 & 4593,116293 & 5214,312526 \\
0,33 & 2343,151 & 2827,93699 & 3479,633555 & 3950,236762 \\
0,5 & 1546,48 & 1866,438414 & 2296,558147 & 2607,156263 \\
1 & 773,24 & 933,2192068 & 1148,279073 & 1303,578131 \\
2 & 386,62 & 466,6096034 & 574,1395366 & 651,7890657 \\
4 & 193,31 & 233,3048017 & 287,0697683 & 325,8945329 \\
5 & 154,648 & 186,6438414 & 229,6558147 & 260,7156263 \\
12 & 64,43666 & 77,76826723 & 95,68992277 & 108,631511 \\
24 & 32,21833 & 38,88413362 & 47,84496139 & 54,31575548 \\
\hline
\end{tabular}

Sumber : Hasil analisis penelitian 2019

Berdasarkan tabel diatas terlihat bahwa intensitas curah hujan yang terjadi di Stasiun Meteorologi Maritim Kendari dengan periode ulang $5,10,25$ dan 50 tahun bervariasi tergantung durasi atau lamanya hujan, dimana intensitas hujan terus mengalami penurunan dengan bertambahnya atau lamanya durasi hujan yang terjadi. jika digrafikkan terlihat seperti gambar 6 


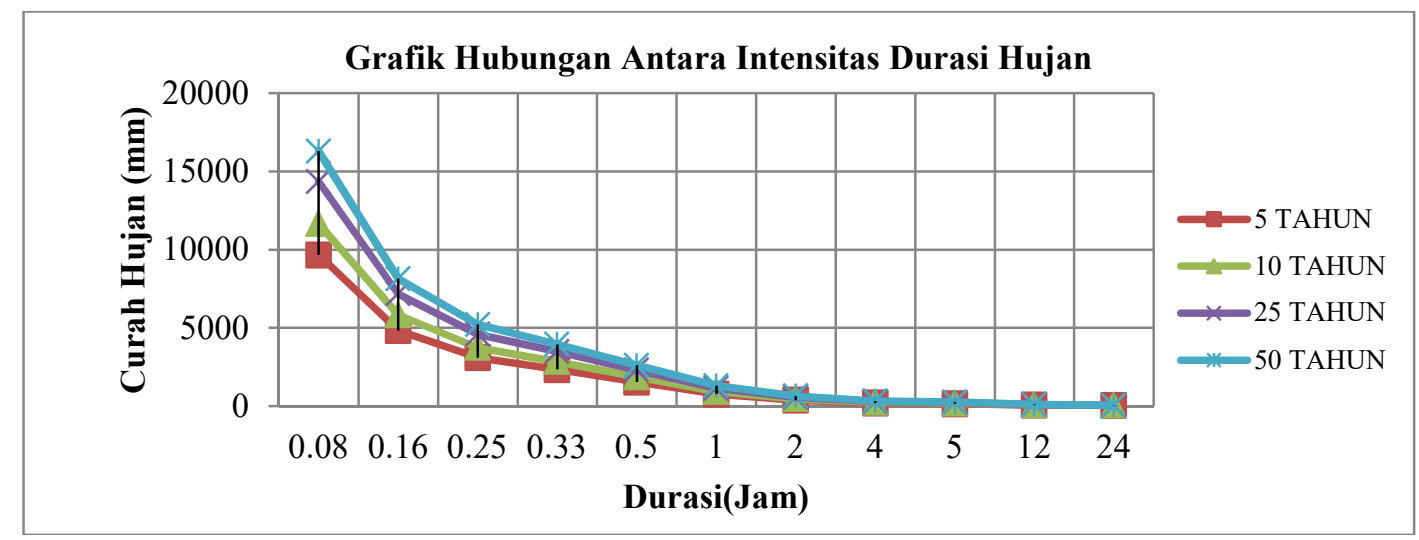

Gambar 6. Grafik hubungan antara intensitas curah hujan TRMM dan durasi hujan di Stasiun Meteorologi Maritim Kendari

Analisis untuk perhitungan intensitas curah hujan rencana dalam periode ulang 5,10 , persamaan Mononobe diperoleh data yang 25 dan 50 tahun dengan menggunakan disajikan dalam Tabel 8

Tabel 8. Besaran intensitas curah hujan TRMM dengan durasi waktu 24 jam di Stasiun

Klimatologi Ranomeeto

\begin{tabular}{c|c|c|c|c}
\hline \multirow{2}{*}{$\begin{array}{c}\text { Durasi } \\
\text { (Jam) }\end{array}$} & \multicolumn{4}{|c}{ Curah Hujan Harian Maksimum 24 Jam (R24) (mm/24 jam) } \\
\cline { 2 - 5 } & $\mathbf{5}$ Tahun & $\mathbf{1 0}$ Tahun & $\mathbf{2 5}$ Tahun & $\mathbf{5 0}$ Tahun \\
\cline { 2 - 5 } & $\mathbf{2 5 7 9 , 2}$ & $\mathbf{3 1 3 9 , 6 1}$ & $\mathbf{3 9 0 5 , 0 6}$ & $\mathbf{4 4 5 7 , 8 2}$ \\
\cline { 2 - 5 } & \multicolumn{2}{|c}{ Intensitas Hujan Rencana dengan rumus Mononobe (mm/Jam) } \\
\hline 0,08 & 11176,98 & 13605,52494 & 16922,60861 & 19317,99848 \\
0,16 & 5588,492 & 6802,762471 & 8461,304306 & 9658,999238 \\
0,25 & 3576,635 & 4353,767981 & 5415,234756 & 6181,759512 \\
0,33 & 2709,572 & 3298,309077 & 4102,450573 & 4683,151145 \\
0,5 & 1788,317 & 2176,883991 & 2707,617378 & 3090,879756 \\
1 & 894,1587 & 1088,441995 & 1353,808689 & 1545,439878 \\
2 & 447,0793 & 544,2209976 & 676,9043445 & 772,719939 \\
4 & 223,5397 & 272,1104988 & 338,4521723 & 386,3599695 \\
5 & 178,8317 & 217,6883991 & 270,7617378 & 309,0879756 \\
12 & 74,51322 & 90,70349961 & 112,8173908 & 128,7866565 \\
24 & 37,25661 & 45,3517498 & 56,40869538 & 64,39332825 \\
\hline
\end{tabular}

Sumber : Hasil analisis penelitian 2019

Berdasarkan tabel diatas terlihat bahwa intensitas curah hujan yang terjadi di Stasiun Klimatologi Ranomeeto dengan periode ulang $5,10,25$ dan 50 tahun bervariasi tergantung durasi atau lamanya hujan, dimana intensitas hujan terus mengalami penurunan dengan bertambahnya atau lamanya durasi hujan yang terjadi. jika digrafikkan terlihat seperti gambar 7 


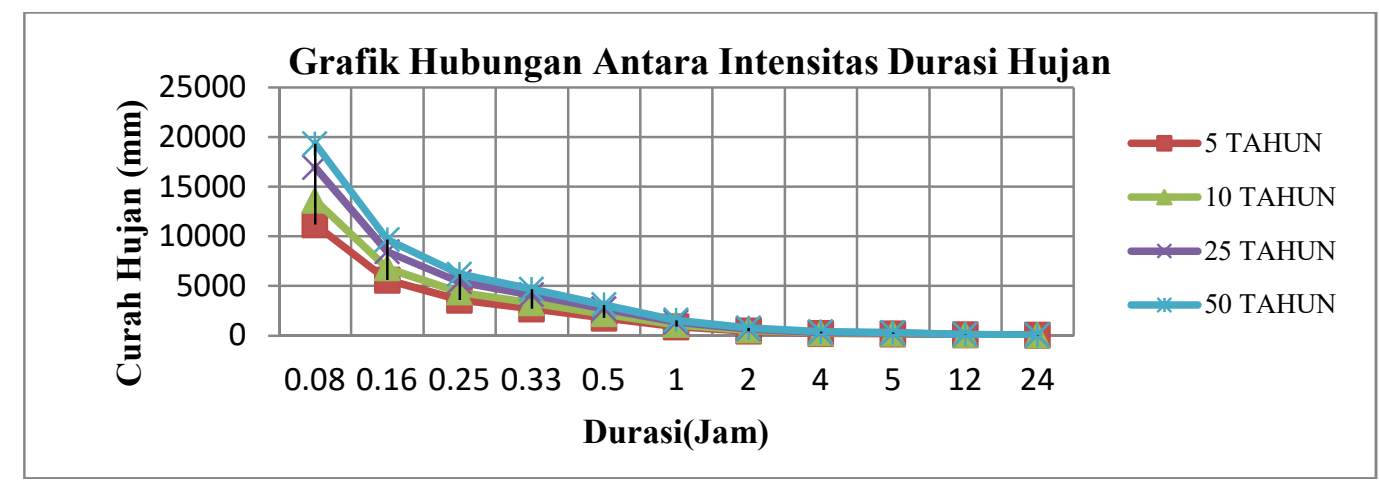

Gambar 7. Grafik hubungan antara intensitas curah hujan TRMM dan durasi hujan di Stasiun Klimatologi Ranomeeto

Analisis untuk perhitungan intensitas curah hujan rencana dalam periode ulang 5,10 , persamaan Mononobe diperoleh data yang 25 dan 50 tahun dengan menggunakan

Tabel 9. Besaran intensitas curah hujan TRMM dengan durasi waktu 24 jam di Stasiun Meteorologi Sangia Ni Bandera

\begin{tabular}{c|c|c|c|c}
\hline \multirow{2}{*}{$\begin{array}{c}\text { Durasi } \\
\text { (Jam) }\end{array}$} & \multicolumn{4}{|c}{ Curah Hujan Harian Maksimum 24 Jam (R24) (mm/24 jam) } \\
\cline { 2 - 5 } & $\mathbf{5}$ Tahun & $\mathbf{1 0}$ Tahun & $\mathbf{2 5}$ Tahun & $\mathbf{5 0}$ Tahun \\
\cline { 2 - 5 } & $\mathbf{3 9 5 6 , 6 4}$ & $\mathbf{5 4 7 2 , 3 6}$ & $\mathbf{7 5 0 9 , 9 1}$ & $\mathbf{8 9 8 1 , 2 9}$ \\
\cline { 2 - 5 } & \multicolumn{2}{|c}{ Intensitas Hujan Rencana } & dengan rumus Mononobe (mm/Jam) \\
\hline 0,08 & 17146,13 & 23714,51565 & 32544,2548 & 38920,49175 \\
0,16 & 8573,065 & 11857,25782 & 16272,1274 & 19460,24587 \\
0,25 & 5486,762 & 7588,645007 & 10414,16154 & 12454,55736 \\
0,33 & 4156,638 & 5748,97349 & 7889,516315 & 9435,270727 \\
0,5 & 2743,381 & 3794,322503 & 5207,080768 & 6227,27868 \\
1 & 1371,69 & 1897,161252 & 2603,540384 & 3113,63934 \\
2 & 685,8452 & 948,5806258 & 1301,770192 & 1556,81967 \\
4 & 342,9226 & 474,2903129 & 650,885096 & 778,409835 \\
5 & 274,3381 & 379,4322503 & 520,7080768 & 622,727868 \\
12 & 114,3075 & 158,096771 & 216,9616987 & 259,469945 \\
24 & 57,15377 & 79,04838549 & 108,4808493 & 129,7349725 \\
\hline
\end{tabular}

Sumber : Hasil analisis penelitian 2019

Berdasarkan tabel diatas terlihat bahwa intensitas curah hujan yang terjadi di Stasiun Meteorologi Sangia Ni Bandera dengan periode ulang $5,10,25$ dan 50 tahun bervariasi tergantung durasi atau lamanya hujan, dimana intensitas hujan terus mengalami penurunan dengan bertambahnya atau lamanya durasi hujan yang terjadi, jika digrafikkan terlihat seperti gambar 8

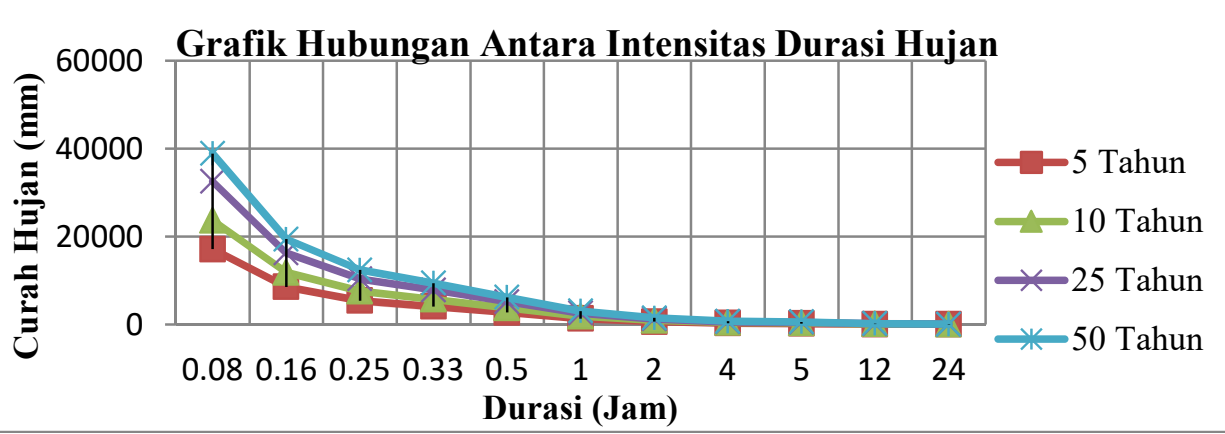


Gambar 8. Grafik hubungan antara intensitas curah hujan TRMM dan durasi hujan di Stasiun Meteorologi Sangia Ni Bandera

Analisis untuk perhitungan intensitas curah hujan rencana dalam periode ulang 5,10 , persamaan Mononobe diperoleh data yang 25 dan 50 tahun dengan menggunakan disajikan dalam tabel 10

Tabel 10. Besaran intensitas curah hujan TRMM dan durasi hujan di Stasiun Meteorologi Betoambari

\begin{tabular}{|c|c|c|c|c|}
\hline \multirow{4}{*}{$\begin{array}{l}\text { Durasi } \\
\text { (Jam) }\end{array}$} & \multicolumn{4}{|c|}{ Curah Hujan Harian Maksimum 24 Jam (R24) (mm/24 jam) } \\
\hline & 5 Tahun & 10 Tahun & 25 Tahun & 50 Tahun \\
\hline & 3158,2 & 4396,1 & 6060,19 & 7261,89 \\
\hline & \multicolumn{4}{|c|}{ Intensitas Hujan Rencana dengan rumus Mononobe ( $\mathrm{mm} / \mathrm{Jam})$} \\
\hline 0,08 & 13686,08 & 19050,53436 & 26261,88163 & 31469,45815 \\
\hline 0,16 & 6843,042 & 9525,267182 & 13130,94082 & 15734,72908 \\
\hline 0,25 & 4379,547 & 6096,170996 & 8403,802122 & 10070,22661 \\
\hline 0,33 & 3317,839 & 4618,311361 & 6366,516759 & 7628,959552 \\
\hline 0,5 & 2189,774 & 3048,085498 & 4201,901061 & 5035,113305 \\
\hline 1 & 1094,887 & 1524,042749 & 2100,950531 & 2517,556652 \\
\hline 2 & 547,4434 & 762,0213745 & 1050,475265 & 1258,778326 \\
\hline 4 & 273,7217 & 381,0106873 & 525,2376327 & 629,3891631 \\
\hline 5 & 218,9774 & 304,8085498 & 420,1901061 & 503,5113305 \\
\hline 12 & 91,24057 & 127,0035624 & 175,0792109 & 209,7963877 \\
\hline 24 & 45,62028 & 63,50178121 & 87,53960544 & 104,8981938 \\
\hline
\end{tabular}

Sumber : Hasil analisis penelitian 2019

Berdasarkan tabel diatas terlihat bahwa intensitas curah hujan yang terjadi di Stasiun Meteorologi Beto Ambari dengan periode ulang $5,10,25$ dan 50 tahun bervariasi tergantung durasi atau lamanya hujan, dimana intensitas hujan terus mengalami penurunan dengan bertambahnya atau lamanya durasi hujan yang terjadi. jika digrafikkan terlihat seperti gambar 9

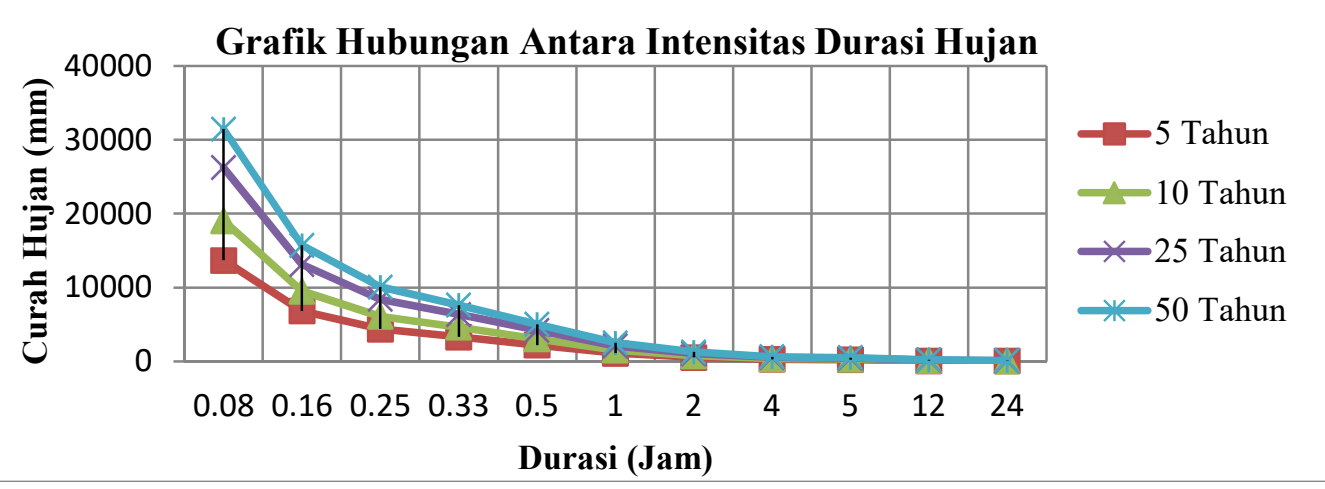

Gambar 9. Grafik hubungan antara intensitas curah hujan TRMM dan durasi hujan di Stasiun Meteorologi Betoambari 


\section{KESIMPULAN}

1. Hasil analisis untuk menentukan pola curah hujan di Sulawesi Tenggara dengan menggunakan data satelit TRMM yang dibandingkan dengan hasil yang diperoleh dengan menggunakan data dari Stasiun menunjukkan kesesuaian pola grafik untuk curah hujan bulanan selama 10 tahun (2009-2018), dimana pola curah hujan tersebut merupakan pola Region A tipe Monsunal dengan ciri terjadi puncak musim hujan yang terjadi antara bulan Desember, Januari, Februari dan puncak musim kemarau terjadi antara bulan Agustus dan September. Untuk intensitas curah hujan didapatkan bahwa data dari TRMM bisa dilakukan perhitungan intensitas berdasarkan nilai korelasi yang didapatkan. Intensitas hujan yang lebat hanya terjadi pada waktu yang pendek (5 atau 4 jam) dan sebaliknya hujan yang lama, misalnya 12 jam dan 24 jam , mempunyai intensitas hujan yang kecil, dan untuk hasil analisis didapatkan bahwa kecendrungan intensitas curah hujan mengalami kenaikan dengan kala ulang yang lebih lama.

\section{DAFTAR PUSTAKA}

Azwar., Saifuddin. 2005. Signifikan Atau Sangat Signifikan.
Buletin
Psikologi, Yogyakarta, Vo.13, No. 1. p.1-10

Mulyono, Dodo. 2014. Analisis Karakteristik Curah Hujan Di Wilayah Kabupaten Garut Selatan. Jurnal Konstruksi Sekolah Tinggi Teknologi Garut. Vo. 1, No. 1. p. 13-23

Muttaqin, Aryo., Tukiyat., Purwadi., dan Tris, Hakim. Seto., 2014. Korelasi Antara Data Curah Hujan Penakar Manual Dan Trmm (Tropical Rainfall Measuring Mission) Giovanni Tovas, Provinsi Riau. Vo.1, No. 2. p. 98-103

Zubaidah, 2012. Analisis Perubahan Curah Hujan Satelit Tropical Measuring Mission (TRMM) Tahun 2009 dan Tahun 2010. [skripsi], Banjarmasin:Universitas

Lambung Mangkurat Banjarmasin Fauziyah., Sri. Sobriyah dan Susilowati. 2013. Analisis Karakteristik dan Intensitas Hujan Kota Surakarta, EJurnal Matriks Teknik Sipil Vo.1, No. 2.p. 139-147

Raharja, 2007. Analisis Curah Hujan Bulanan Di Sumatera Selatan dan Kaitannya Dengan Indeks Monsun Indonesia. [Skripsi]. Jakarta: Sekolah Tinggi Meteorologi Klimatologi dan Geofisika 